\title{
PENGARUH PERKEMBANGAN USAHA MIKRO KECIL DAN MENENGAH TERHADAP PERTUMBUHAN EKONOMI DI ASEAN 4 (INDONESIA, MALAYSIA, FILIPINA, THAILAND)
}

\author{
Yusrin Fauziah ${ }^{1}$ \\ Email: yusrin.fauziah24@gmail.com
}

\begin{abstract}
ASEAN is an organization in the Southeast Asian region which has ten member countries. Among the ten ASEAN member countries, there are four countries that have the same characteristics, namely Indonesia, Malaysia, the Philippines and Thailand. The four countries are developing countries with low to medium income, where the economy is supported by Micro, Small and Medium Enterprises (MSMEs). This study aims to see the effect of the number of workers, the value of exports and the value of MSME capital loans on economic growth in ASEAN 4. The MSMEs studied are MSMEs in four ASEAN countries (Indonesia, Malaysia, the Philippines and Thailand) since 2009-2018. The analytical tool used is multiple linear regression using panel data by performing statistical tests ( $F$ test, $t$ test and $R 2$ test) and classical assumption tests (normality, multicollinearity, heteroscedasticity, and autocorrelation). Data analysis shows that the number of workers and the value of MSME capital loans have a positive and significant effect on economic growth in ASEAN 4. Meanwhile, the export value of MSMEs has a positive but not significant effect on economic growth in ASEAN 4.
\end{abstract}

Keywords: MSMEs, Employment, Exports, Capital Loans and Economic Growth.

\section{PENDAHULUAN}

Pertumbuhan ekonomi adalah kegiatan dalam perekonomian yang dapat menyebabkan bertambahnya jumlah barang maupun jasa yang ada dimasyarakat sehingga dapat meningkatkan kemakmuran masyarakat (Sukirno 2007). Literatur lainnya juga mendefinisikan pertumbuhan ekonomi sebagai kenaikan GDP/GNP tanpa memperhatikan besar kecilnya tingkat pertumbuhan penduduk dan ada tidaknya perubahan struktur ekonomi di suatu wilayah. Pertumbuhan ekonomi suatu wilayah dapat dilihat dari pendapatan nasional wilayah tersebut.

\footnotetext{
${ }^{1}$ Corresponding author: University of Jember, Jl. Kalimantan No.37, 68121, Jawa Timur, Indonesia
} 
Pendapatan nasional sering diukur dengan Produk Domestik Bruto (PDB) yang diartikan sebagai harga pasar (market prices) atau total nilai dari seluruhan barang dan jasa yang dihasilkan selama kurun waktu tertentu. Sehingga, PDB merupakan bagian penting untuk melihat pertumbuhan ekonomi disuatu negara, apabila PDB negara dari tahun ketahun terjadi peningkatan maka dapat dikatakan perekonomian negara tersebut baik atau stabil. PDB dalam bahasa internasional disebut juga Gross Domestic Product (GDP) (Hapsari et al. 2014).

Menurut Teori Schumpeter menyatakan bahwa pertumbuhan ekonomi suatu wilayah dapat terjadi karena adanya pengusaha dan inovasi baru. Pengusaha mrupakan suatu golongan yang terus melakukan pembaharuan dan inovasi dalam melakukan kegiatan ekonomi. Sehingga, dapat menciptakan investasi baru, produk baru, dan dapat meningkatkan efisiensi dalam memproduksi suatu barang maupun jasa. Hal tersebut dapat memperluas pangsa pasar baik pasar domestik maupun pasar internasional untuk melakukan ekspor. Pembukaan dan perluasan pasar dapat menciptakan lapanagan kerja baru hingga dapat menyerap tenaga kerja lebih banyak setiap tahunnya. Dari pernyataan tersebut, pengusaha juga sering disebut dengan produsen karena memiliki fungsi dan peran yang sama (Sukirno 2007).

Menurut Teori Ekonomi Klasik, memaparkan bahwa produsen memiliki beberapa peran untuk meningkatkan pertumbuhan ekonomi disuatu negara. Peran produsen yang dimaksud, antara lain mempercepat proses industrialisasi, menciptakan lapangan kerja, menyediakan barang maupun jasa bagi masyarakat yang berpenghasilan rendah. Peran produsen yang paling popular dan sangat penting adalah kemampuannya menyediakan kesempatan kerja. Sedangkan, saat ini banyak produsen yang menjalankan bisnisnya dalam bentuk UMKM, karena memiliki peran komplementer dengan perusahaan-perusahaan besar dalam menyediakan lapangan kerja serta dapat meningkatkan pertumbuhan ekonomi. Teori tersebut sejalan dengan Teori Ekonomi Modern yang memandang bahwa pentingnya eksistensi serta perkembangan UMKM berkaitan dengan spesialisasi yang fleksibel dalam berproduksi dan melakukan kegiatan ekspor. UMKM dapat melakukan spesialisasi dalam proses produksi, sehingga dapat terjadi keterkaitan antara UMKM dengan usaha-usaha besar. Spesialisasi tersebut sangat penting untuk mengembangkan unitunit UMKM, industri besar, maupun perekonomian secara keseluruhan (Tambunan 2000).

Namun, kedua teori tersebut bertentangan dengan teori yang dikembangkan Anderson tahun 1982 yang pesimis terhadap peran dan pengaruh UMKM terhadap pertumbuhan ekonomi suatu negara. Teori Anderson ini memprediksikan bahwa UMKM makin menghilang ketika pembangunan ekonomi semakin maju. Hal tersebut terjadi karena pembangunan ekonomi yang semakin maju akan sejalan dengan perkembangan terknologi yang semakin canggih. Sehingga, UMKM akan tersingkirkan oleh usaha-usaha besar yang sudah memiliki modal besar dan teknologi canggih untuk menghasilkan output dengan kuantitas yang lebih banyak dan kualitas yang lebih bagus (Tambunan 2000).

ASEAN (Association of Southeast Asian Nations) adalah sebuah organisasi yang ada di kawasan Asia Tenggara yang didirikan padata tanggal 8 Agustus 1967 di Bangkok, Thailand. Anggota ASEAN terdiri dari 10 Negara yaitu Indonesia, Singapura, Malaysia, Filipina, Thailand, Brunei Darussalam, Vietnam, Laos, Myanmar dan Kamboja. Di antara sepuluh negara anggota ASEAN, terdapat empat negara yang memiliki karakteristik yang sama, yaitu Indonesia, Malaysia, Filipina dan 
Thailand. Persamaan karakteriktik yang pertama, yaitu empat negara tersebut memiliki pendapatan yang rendah hingga menengah dan empat negara ini sedang berusaha untuk menjadi negara industri baru agar dapat menjadi negara maju. Sehingga, empat negara ini mulai mengikuti model pembangunan ekonomi yang berorientasi ekspor, seperti negara Singapura, Korea Selatan, Taiwan dan Hongkong. Strategi yang dilakukan oleh empat negara tersebut bertujuan untuk mengundang para investor asing untuk membantu perekonomian negara. Kemudian, empat negara ASEAN ini juga memiliki kesamaan geografis yang kaya akan sumber daya alam dimasing-masing negara, sehingga dijuluki negara agraris serta empat negara ini memiliki kesamaan demografis diempat negara ini yaitu memiliki pertumbuhan penduduk terpesat di kawasan ASEAN (Febryani 2017).

Pertumbuhan ekonomi di Asia Tenggara telah ditopang oleh Usaha Mikro Kecil dan Menengah (UMKM), karena UMKM dapat merangsang permintaan domestik, persaingan, inovasi baru dan dapat menciptakan lapangan pekerjaan. Pertumbuhan ekonomi suatu negara yang lambat dapat dipulihkan dengan memperkuat dinamika UMKM. Berdasarkan data Asian Development Bank yang terdapat pada Gambar 1 menunjukkan persentase kontribusi Usaha Mikro Kecil dan Menengah (UMKM) terhadap Gross Domestic Product (GDP) di empat Negara ASEAN pada tahun 2018.

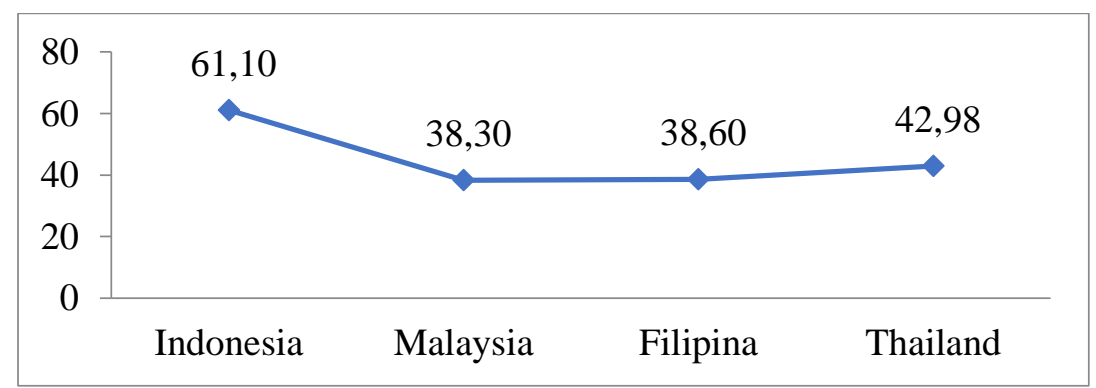

Gambar 1. Persentase Kontribusi UMKM terhadap GDP di ASEAN 4 tahun 2018

(Sumber: Asian Development Bank, 2020)

UMKM memiliki kontribusi yang cukup besar terhadap GDP pada tahun 2018. Peran penting UMKM secara umum dapat dilihat dari perkembangan yang signifikan dan peran UMKM sebagai penyumbang GDP yang cukup besar di empat negara ASEAN. Pada tahun 2018, negara dengan kontribusi UMKM terhadap GDP terbesar yaitu Indonesia, dimana UMKM berkontribusi sebesar $61.1 \%$ dari total GDP usahausaha (UMKM dan UB) yang ada di Indonesia. Hal tersebut disebabkan karena banyaknya jumlah UMKM yang terdapat di Indonesia. Sedangkan, negara dengan kontribusi UMKM terhadap GDP terendah diantara empat negara tersebut yaitu Malaysia, dimana UMKM berkontribusi sebesar 38.3\% dari total GDP usaha-usaha (UMKM dan UB) di negara Malaysia pada tahun 2018. Rendahnya kontribusi UMKM terhadap GDP di Malaysia disebabkan karena sedikitnya jumlah UMKM di Malaysia dibandingkan dengan negara lainnya.

UMKM berperan penting bagi pembangunan ekonomi baik dinegara berkembang maupun dinegara maju, karena UMKM dapat menciptakan lapangan kerja dan meningkatkan pertumbuhan output. Seiring dengan berjalannya waktu, peran UMKM menjadi lebih penting dalam perkembangan ekonomi di dalam negeri karena dampaknya terhadap lapangan kerja yang semakin banyak dan Gross Domestic 
Product (GDP) yang semakin meningkat. UMKM merupakan salah satu bidang ekonomi yang berkontribusi secara signifikan dalam mendorong pertumbuhan ekonomi di suatu Negara. Hal tersebut dikarenakan UMKM tersebar di berbagai wilayah baik di kota maupun di desa, sehingga dapat menyerap tenaga kerja dengan jumlah yang banyak. Menurut penelitian (Hapsari et al. 2014; Anne et al. 2017; Rachman 2017; Rohman 2019; Riswara 2018) menyatakan bahwa tenaga kerja memiliki pengaruh yang signifikan terhadap pertumbuhan ekonomi. Namun, penelitian tersebut berbeda dengan penelitian (Halim 2020; Hidayati 2016) yang menyatakan bahwa tenaga kerja tidak berpengaruh terhadap pertumbuhan ekonomi karena tenaga kerja yang diserap tidak sebanding dengan nilai tambah yang dihasilkan.

UMKM berpotensi besar terhadap peningkatan tenaga kerja sebagai pendorong pertumbuhan ekonomi namun pada kenyataanya UMKM masih menghadapi beberapa kendala dalam bidang internal maupun eksternal yang meliputi produksi, pengolahan, pemasaran modal, dan lainnya. Dari berbagai kendala yang dihadapi UMKM, maka diperlukan strategi seperti kemitraan, bantuan keuangan, dan meningkatkan investasi UMKM. Bantuan keuangan berupa pinjaman modal dapat diperoleh dari pihak bank maupun non-bank. Pinjaman modal sangat penting karena sebagian besar pelaku usaha mengalami hambatan permodalan u ntuk melakukan investasi baru atau dalam melakukan perubahan teknologi. Dalam teori ekonomi mikro dijelaskan bahwa tingginya pinjaman modal yang dilakukan oleh para pelaku usaha dapat meningkatkan akses finansial yang akan mendorong kemampuan usaha dalam melakukan ekspansi usaha dan perluasan pasar. Sehingga, peran pinjaman modal terhadap perekonomian menjadi penting terutama dalam mempercepat laju pertumbuhan ekonomi. Berdasarkan indikator pertumbuhan ekonomi dan alokasi pinjaman terdapat indikasi bahwa pinjaman modal berperan sebagai stimulator pertumbuhan ekonomi (Supartoyo et al. 2018). UMKM juga banyak yang melakukan pinjaman modal kepada pihak perbankan untuk memenuhi kebutuhan modal dalam keberlangsungan UMKM.

Banyaknya pinjaman UMKM untuk proses produksi dan perkembangan UMKM sejalan dengan peningkatan ekspor UMKM, meskipun nilai ekspor UMKM tidak sebesar ekspor yang dilakukan oleh Usaha Besar. Kegiatan ekspor atau perdagangan luar negeri dapat mendorong dan mempercepat perkembangan ekonomi suatu negara. Smith dan Mill berpendapat bahwa terdapat dua keuntungan bagi negara yang melakukan perdagangan luar negeri, yaitu dapat memperluas pasar dengan banyaknya hasil dari kegiatan produksi dan dapat menggunakan teknologi canggih yang dikembangkan oleh luar negeri (Sukirno 2007). Ekspor UMKM berpengaruh signifikan terhadap pertumbuhan ekonomi suatu wilayah (Halim 2020; Rohman 2019). Namun, berdasarkan Tambunan (2000) menyatakan bahwa UMKM mengalami beberapa masalah dalam pelaksanaan ekspor. Hal tersebut dapat dibuktikan dengan penelitian Riswara (2018) yang menyatakan bahwa ekspor yang dilakukan UMKM memiliki hubungan yang tidak signifikan terhadap pertumbuhan ekonomi.

Berdasarkan beberapa teori dan hasil penelitian terdahulu, maka penelitian ini menjadi menarik untuk membahas mengenai "Pengaruh Perkembangan Usaha Mikro Kecil dan Menengah Terhadap Pertumbuhan Ekonomi di ASEAN 4 (Indonesia, Malaysia, Filipina, Thailand)". Penulis ingin meneliti lebih lanjut dan memastikan terkait teori-teori para ilmuan ekonomi apakah masih relevan dengan kondisi saat ini dan ingin mengetahui seberapa besar keterkaitan antar tiga variabel UMKM (tenaga kerja, ekspor dan pinjaman modal) terhadap pertumbuhan ekonomi di ASEAN 4 sebagai variabel dependen. 


\section{KAJIAN LITERATUR DAN PENGEMBANGAN HIPOTESIS 2.1 Pertumbuhan Ekonomi Klasik}

Dalam Teori Klasik, Adam Smith yang menjelaskan tentang teori spesialisasi dan pembagian tenaga kerja. Menurut Smith, pertumbuhan penduduk yang terus meningkat akan dapat menambah jumlah output yang dihasilkan melalui penambahan tenaga kerja dan adanya ekspansi pasar domestik maupun pasar internasional. David Ricardo dan Mill memaparkan bahwa terdapat beberapa faktor yang dapat mempengaruhi pertumbuhan ekonomi, seperti jumlah penduduk, jumlah barang modal, sumberdaya alam dan teknologi. Selain itu, Teori Klasik juga menjelakan tentang perdagangan internasional untuk meningkatkan pertumbuhan ekonomi. Dalam teori ini dijelakan bahwa perdagangan internasional didukung dengan adanya Absolute Advantage, Comparative Advantage, dan Comparative Cost (Sukirno 2007).

\subsection{Tenaga Kerja}

Beberapa ahli ekonomi menjelaskan mengenai teori tenaga kerja, salah satunya Adam Smith yang menjelaskan tentang teori spesialisasi dan pembagian tenaga kerja. Menurut Smith pertumbuhan penduduk yang terus meningkat akan dapat menambah jumlah output yang dihasilkan melalui penambahan tenaga kerja dan adanya ekspansi pasar domestik maupun pasar internasional. Jika tingkat pertumbuhan penduduk tinggi maka akan menyebabkan tingginya pertumbuhan tenaga kerja. Tenaga kerja dengan usia muda yang lebih banyak akan mendorong adanya perubahan teknologi dalam kegiatan produksi dan mendorong pertumbuhan ekonomi melalui mobilitas dan adaptasi. Selain itu tingkat kepadatan penduduk akan menyebabkan penggunaan sumber daya alam yang lebih efisien, meningkatnya tabungan dan dapat mendorong pertumbuhan ekonomi (Sukirno 2007).

\subsection{Ekspor}

Teori ekspor telah dibahas oleh beberapa hali ekonom, seperti Adam Smith, JS Mill dan David Ricardo tentang perdagangan luar negeri. Adaam Smith menjelaskan tentang kemanfaatan absolut (Absolute Advantage), teori ini menjelaskan tentang variabel riil dalam proses produksi disuatu negara seperti tenaga kerja. Tenaga kerja digunakan sebagai ukuran untuk mengukur besar kecilnya nilai suatu barang yang dihasilkan, jika nilai suatu barang tinggi menunjukkan banyaknya jumlah tenaga kerja yang digunakan dalam proses menghasilkan barang tersebut. Selanjutnya, teori ekspor yang dijelaskan oleh JS Mill tentang kemanfaatan relatif (Comparative Advantage), teori tersebut menjelaskan bahwa suatu negara akan melakukan kegiatan ekspor jika dapat menghasilkan suatu barang dengan biaya yang lebih murah dibandingkan dengan negara lain atau dengan kata lain negara tersebut memiliki comparative advantage. Teori yang disampaikan oleh Smith dan JS Mill tentang ekspor dapat mendorong pertumbuhan ekonomi dengan adanya perluasan pasar atas output yang dihasilkan, selain itu kegiatan ekspor juga dapat memungkinkan penggunaan teknologi yang dikembangkan diluar negeri yang tentunya lebih canggih daripada teknologi yang telah digunakan di dalam negeri. David Ricardo juga berpendapat tentang biaya relatif (Comparative Cost), yang menjelaskan mengenai nilai suatu barang dilihat dari kuantitas faktor produksi yaitu tenaga kerja yang digunakan dalam proses produksi (labor cost value theory). Maka suatu negara akan melakukan perdagangan luar negeri (ekspor) jka setiap negara memiliki comparative cost yang paling kecil (Sukirno 2007). 


\subsection{Pinjaman Modal}

Dalam Teori Neo-klasik menjelaskan tentang fungsi produksi suatu barang atau jasa tergantung pada modal dan tenaga kerja yang digunakan dalam proses produksi. Dalam kegiatan produksi banyak kendala yang dihadapi para pelaku usaha yang meliputi produksi, pengolahan, pemasaran modal, dan lainnya. Dari berbagai kendala yang dihadapi, maka diperlukan strategi seperti kemitraan dan bantuan keuangan. Bantuan keuangan berupa pinjaman modal dapat diperoleh dari pihak bank maupun non-bank. Pinjaman modal sangat penting karena sebagian besar pelaku usaha mengalami hambatan permodalan untuk melakukan investasi baru atau dalam melakukan perubahan teknologi. Dalam teori ekonomi mikro dijelaskan bahwa tingginya pinjaman modal yang dilakukan oleh para pelaku usaha dapat meningkatkan akses finansial yang akan mendorong kemampuan usaha dalam melakukan ekspansi usaha dan perluasan pasar. Sehingga, peran pinjaman modal terhadap perekonomian menjadi penting terutama dalam mempercepat laju pertumbuhan ekonomi. Berdasarkan indikator pertumbuhan ekonomi dan alokasi pinjaman terdapat indikasi bahwa pinjaman modal berperan sebagai stimulator pertumbuhan ekonomi (Supartoyo et al. 2018).

\subsection{Usaha Mikro Kecil dan Menengah (UMKM)}

Teori Modern yang dikemukakan oleh Piore dan Sabel tahun 1984 menjelaskan tetang pentingnya eksistensi serta perkembangan UMKM berkaitan dengan spesialisasi yang fleksibel dalam berproduksi dan melakukan kegiatan ekspor. UMKM dapat melakukan spesialisasi dalam proses produksi, sehingga dapat terjadi keterkaitan antara UMKM dengan usaha-usaha besar. Spesialisasi tersebut sangat penting untuk mengembangkan unit-unit UMKM, industri besar, maupun perekonomian secara keseluruhan. Keterkaitan yang dimaksud yaitu pola hubungan antar dua atau lebih perusahaan yang saling memberikan keuntungan. Dalam hal ini, posisi UMKM sebagai penyedia berbagai input yang dibutuhkan oleh usaha yang berskala besar. Di berbagai negara maju, seperti Eropa, AS, Kore, dan Jepang posisi UMKM sangat penting sebagai industri pendukung yang menyediakan input maupun komponen lainnya yang dibutuhkan oleh usaha besar dalam memproduksi suatu output. Namun berdasarkan Teori Anderson ini memprediksikan bahwa UMKM makin menghilang ketika pembangunan ekonomi semakin maju. Hal tersebut terjadi karena pembangunan ekonomi yang semakin maju akan sejalan dengan perkembangan terknologi yang semakin canggih. Sehingga, UMKM akan tersingkirkan oleh usahausaha besar yang sudah memiliki modal besar dan teknologi canggih untuk menghasilkan output dengan kuantitas yang lebih banyak dan kualitas yang lebih bagus (Tambunan 2000).

\section{METODE PENELITIAN}

\subsection{Jenis Penelitian}

Jenis penelitian ini yaitu penelitian kuantitatif. Penelitian kuantitatif adalah suatu metode penelitian dengan cara meneliti hubungan antar variabel untuk menguji beberapa teori tertentu. Dalam penelitian kuantitatif, variabel yang digunakan berupa data angka-angka yang dapat dianalisis. Penelitian kuantitatif memiliki asumsi untuk menguji teori-teori secara deduktif, mencegah muncuknya bias, mengontrol penjelas alternatif, mampu menggeneralisasi dan menerapkan kembali penemuannya. 


\subsection{Unit Analisis}

Unit analisis dari penelitian ini adalah jumlah tenaga kerja UMKM, nilai ekspor UMKM, dan nilai pinjaman modal UMKM di ASEAN 4 (Indonesia, Malaysia, Filipina, Thailand), maka selanjutnya akan dicari seberapa besar pengaruh dari beberapa variabel independen seperti jumlah tenga kerja UMKM, nilai ekspor UMKM, dan nilai pinjaman modal UMKM terhadap pertumbuhan ekonomi di ASEAN 4 yang merupakan variabel dependen.

\subsection{Waktu dan Tempat Penelitian}

Waktu penelitian dilakukan dalam periode 10 tahun yaitu dari tahun 20092018. Pemilihan rentan waktu penelitian dikarenakan pada tahun 2009 , terjadinya krisis finansial global yang tak hanya dirasakan Indonesia tetapi juga ke negara lain. Bank Sentral Amerika Serikat (The Fed) menaikkan suku bunga yang membuat harga komoditas global naik. Sehingga ditahun tersebut terjadi fluktuasi pertumbuhan ekonomi di berbagai negara khususnya di ASEAN 4 (Indonesia, Malaysia, Filipina, Thailand).

Tempat penelitian yaitu Indonesia, Malaysia, Filipina dan Thailand, alasan pemilihan tempat penelitian dikarenakan keempat negara ini masing-masing negara memiliki pendapatan yang rendah hingga menengah dan empat negara ini sedang berusaha untuk menjadi negara industri baru agar dapat menjadi negara maju. Sehingga, empat negara ini mulai mengikuti model pembangunan ekonomi yang berorientasi ekspor, seperti negara Singapur, Korea Selatan, Taiwan dan Hongkong. Strategi yang dilakukan oleh empat negara tersebut bertujuan untuk mengundang para investor asing untuk membantu perekonomian negara. Kemudian, empat negara ASEAN ini juga memiliki kesamaan geografis yang kaya akan sumber daya alam dimasing-masing negara, sehingga dijuluki negara agraris serta empat negara ini memiliki kesamaan demografis diempat negara ini yaitu memiliki pertumbuhan penduduk terpesat di kawasan ASEAN.

\subsection{Jenis dan Sumber Data}

Jenis data dalam penelitian ini yaitu data sekunder berupa data panel. Data sekunder merupakan suatu data atau keterangan yang dapat diperoleh secara tidak langsung atau dengan kata lain data diperoleh melalui sumber perantara, baik dari pihak lain atau dari subjek penelitian. Data sekunder biasanya berupa data dokumentasi atau laporan yang telah tersedia. Sedangkan data panel adalah gabungan dari data cross section dan time series. Data cross section dalam penelitian ini yaitu UMKM diempat negara ASEAN (Indonesia, Malaysia, Filipina dan Thailand), kemudian data time series sebanyak 10 tahun dari tahun 2009-2018. Data sekunder berupa data panel dalam penelitian ini diperoleh dari Asia Development Bank dan data pendukung lainnya seperti buku, jurnal, artikel dan literatur pustaka lainnya.

\subsection{Metode Analisis}

Analisis Regresi Linier Berganda digunakan untuk memperkirakan besar variabel dependen dengan data variabel independen yang telah diketahui besaran nilainya. Agar dapat mengetahui pengaruh jumlah tenaga kerja UMKM, nilai ekspor UMKM, dan nilai pinjaman UMKM terhadap pertumbuhan ekonomi di ASEAN 4, maka digunakan analisis regresi linier berganda menggunakan data panel. Model penelitian yang digunakan dalam penelitian ini yaitu model perhitungan pertumbuhan 
ekonomi yang disebabkan adanya perkembangan UMKM. Dimana pertumbuhan ekonomi mempunyai fungsi dari jumlah tenaga kerja UMKM, nilai ekspor UMKM, dan nilai pinjaman modal UMKM. Satuan dari masing-masing variabel ini yaitu menggunakan persen, yang merupakan persentase dari masing-masing variabel (pertumbuhan ekonomi, tenaga kerja, ekspor, pinjaman modal) yang dilakukan oleh semua usaha baik UMKM maupun UB di masing-masing negara. Persamaan analisis data panel dapat ditulis sebagai berikut:

Di mana:

$$
\begin{gathered}
Y_{i t}=\beta_{0}+\beta_{1} X_{1 i t}+\beta_{2} X_{2 i t}+\beta_{3} X_{3 i t}+\varepsilon_{i t} . \\
Y_{i t}=\beta_{0}+\beta_{1} L_{i t}+\beta_{2} X_{i t}+\beta_{3} I_{i t}+\varepsilon_{i t} .
\end{gathered}
$$

$\begin{array}{ll}\mathrm{Y}_{\text {it }} & : \text { Pertumbuhan Ekonomi di ASEAN } 4 \\ \mathrm{~L}_{\mathrm{it}} & : \text { Jumlah Tenaga Kerja (pensen) untuk negara ke- } i \text { dan waktu ke- } t \\ \mathrm{X}_{\mathrm{it}} & : \text { Nilai Ekspor (persen) untuk negara ke- } i \text { dan waktu ke- } t \\ \mathrm{I}_{\mathrm{it}} & : \text { Nilai Pinjaman modal (persen) untuk negara ke- } i \text { dan waktu ke- } t \\ \beta 1, \beta 2, \beta 3 & : \text { Slope } \\ \beta 0 & : \text { Intersep } \\ \varepsilon & : \text { Error Term } \\ i & : \text { Cross Section } \\ t & : \text { Time Series }\end{array}$

\section{HASIL PENELITIAN DAN PEMBAHASAN}

\subsection{Hasil Penelitian}

Tahap pertama dalam penelitian yang menggunakan metode Panel Least Square (PLS) yaitu memilih model regresi data panel terbaik yang akan digunakan dalam penelitian. Dalam tahap ini, pengujian pertama dilakukan dengan menggunakan Uji Chow dimana uji ini dilakukan untuk memilih model yang terbaik antara Common Effect Model dan Fixed Effect Model.

Tabel 1. Hasil Pengujian Uji Chow

\begin{tabular}{lccc}
\hline \hline Effects Test & Statistic & d.f. & Probabilitas \\
\hline \hline Cross-section F & 4.96417 & $(3,33)$ & 0.0059 \\
Cross-section Chi-square & 14.89806 & 3 & 0.0019 \\
\hline \hline
\end{tabular}

Sumber: Data diolah, 2021

Hasil pengujian dengan menggunakan Uji Chow menunjukkan nilai probabilitas Chi Square sebesar 0.0019. Apabila probabilitas Chi Square memiliki nilai yang lebih kecil sama dengan dari pada nilai kritis $(\alpha=5 \%=0.05)$ maka dapat disimpulkan bahwa model fixed effect adalah model yang terbaik dibandingkan dengan model common effect atau $\mathrm{H}_{0}$ ditolak dan $\mathrm{H}_{1}$ diterima. Ketika $\mathrm{H}_{1}$ diterima yaitu model fixed effect yang lebih baik, maka selanjutnya dilakukan uji Hausman.

Uji Hausman digunakan untuk memilih model yang terbaik diantara model fixed effect dan model random effect. Pengujian ini dilakukan karena hasil pengujian sebelumnya menunjukkan jika model fixed effect sebagai model terbaik dibandingkan dengan model common effect. Maka dilakukan pengujian kedua dengan menggunakan Uji Hausman untuk mengetahui apakah model fixed effect masih menjadi model yang terbaik jika dibandingkan dengan model random effect, atau malah sebaliknya model random effect menjadi model yang terbaik. 
Tabel 2. Hasil Pengujian Uji Hausman

\begin{tabular}{lccc}
\hline \hline Test Summary & Chi-Sq Statistic & Chi-Sq. d.f. & Probabilitas \\
\hline \hline Cross-section Random & 14.892509 & 3 & 0.0019 \\
\hline \hline Sumber: Data diolah, 2021 & & &
\end{tabular}

Berdasarkan hasil dari pengujian Uji Hausman menunjukkan nilai probabilitas sebesar 0.019. Nilai probabilitas tersebut jika dibandingkan dengan nilai kritis atau alfa $(\alpha=5 \%=0.05)$, menunjukkan nilai probabilitas lebih kecil sama dengan dari 0.05 . Maka dapat disimpulkan jika model yang terbaik tetap model fixed effect, atau dengan kata lain $\mathrm{H}_{0}$ ditolak dan $\mathrm{H}_{1}$ diterima. Ketika $\mathrm{H}_{1}$ diterima yaitu model fixed effect yang lebih baik dari pada model random effect. Sehingga, dalam penelitian ini model yang terbaik dan yang terpilih yaitu model regresi fixed effect. Pada penelitian ini, pengujian model regresi hanya dilakukan dengan dua pengujian yaitu menggunakan Uji Chow dan Uji Hausman. Sedangkan uji yang ketiga yaitu Uji lagrange multiplier tidak perlu dilakukan karena jika hasil pengujian menggunakan Uji Chow dan Uji Hasuman sudah dilakukan dan menunjukkan bahwa model fixed effect yang terbaik, maka tidak perlu dilakukan pengujian antaran model common effect dengan random effect menggunakan Uji Lagrange Multiplier.

Pemilihan model regresi yang terbaik sudah dilakukan dan menghasilkan Fixed Effect Model sebagai model regresi yang terbaik. Selanjutnya dilakukan estimasi dengan menggunakan metode regresi data panel yang nantinya akan menjelaskan hasil estimasi dari pengujian secara simultan terhadap semua variabel independen menggunakan Uji-F. Selain itu, untuk menjelaskan hasil estimasi dari pengujian setiap variabel independen secara parsial menggunakan Uji-t. Kemudian untuk melihat besarnya pengaruh dari variabel independen terhadap variabel dependen dapat dilihat dengan menggunakan $R$-squared dan Adjusted $\mathrm{R}^{2}$.

Tabel 3. Hasil Estimasi Metode PLS dengan Fixed Effect Model

\begin{tabular}{lccc}
\hline \hline Variabel & Coefficient & t-Statistic & Probabilitas \\
\hline \hline C & 17.23902 & 2.181047 & 0.0364 \\
TENAGA KERJA & 0.237263 & 1.970915 & 0.0572 \\
UMKM & 0.110313 & 0.543018 & 0.5908 \\
EKSPOR UMKM & 0.366886 & 2.191815 & 0.0356 \\
PINJAMAN UMKM & & 0.981222 & \\
\hline \hline R-squared & & 0.977808 & \\
Adjusted R-squared & & 287.3947 & \\
F-Statistic & 0.000000 & \\
Prob (F-Statistic) & & 1.688298 & \\
t-tabel & & & \\
\hline \hline
\end{tabular}

Sumber: Data diolah, 2021

Tabel diatas menunjukkan hasil estimasi regresi data panel dengan metode fixed effect model yang dapat dijelaskan dengan persamaan regresi sebagai berikut. Pertumbuhan Ekonomi $=17.23902+0.237263$ Tenaga Kerja UMKM +0.110313 Ekspor UMKM + 0.3668866 Pinjaman UMKM 
1. Konstanta

Berdasarkan hasil estimasi dengan menggunakan fixed effect model, maka dapat dihasilkan nilai konstanta sebesar 17.23902. Hal tersebut berarti bahwa apabila tenaga kerja UMKM, ekspor UMKM dan pinjaman UMKM diasumsikan konstan. Dengan kata lain, apabila nilai tenaga kerja, ekspor dan pinjaman sebesar 0 maka pertumbuhan ekonomi sebesar 17.23902.

2. Tenaga Kerja UMKM

Berdasarkan hasil estimasi regresi data panel dengan menggunakan fixed effect model, diperoleh nilai koefisien dari variabel tenaga kerja UMKM sebesar 0.237263. Hal tersebut berarti bahwa setiap perubahan sebesar satu satuan dengan asumsi variabel lainnya dianggap tetap, maka pertumbuhan ekonomi akan mengalami peningkatan sebesar 0.237263 . Selanjutnya, variabel tenaga kerja UMKM memiliki nilai probabilitas sebesar 0.0572 sama dengan nilai $\alpha=5 \%$ yang berarti tenaga kerja UMKM memiliki pengaruh yang signifikan terhadap pertumbuhan ekonomi.

3. Ekspor UMKM

Hasil estimasi regresi data panel dengan menggunakan fixed effect model, diperoleh nilai koefisien dari variabel ekspor UMKM sebesar 0.110313. Hal tersebut berarti bahwa setiap perubahan sebesar satu satuan dengan asumsi tenaga kerja dan pinjaman UMKM dianggap tetap, maka akan meningkatkan pertumbuhan ekonomi sebesar 0.110313. Selain itu, variabel ekspor UMKM memiliki nilai probabilitas sebesar 0.5908 lebih besar dari $\alpha=5 \%$ yang berarti ekspor UMKM meemiliki pengaruh yang signifikan terhadap pertumbuhan ekonomi.

4. Pinjaman modal UMKM

Hasil estimasi regresi data panel dengan menggunakan fixed effect model, diperoleh nilai koefisien dari variabel pinjaman modal UMKM sebesar 0.366886. Hal tersebut berarti bahwa setiap perubahan sebesar satu satuan dengan asumsi tenaga kerja dan pinjaman modal UMKM dianggap tetap, maka akan meningkatkan pertumbuhan ekonomi sebesar 0.366886. Selain itu, variabel pinjaman modal UMKM memiliki nilai probabilitas sebesar 0.0356 lebih kecil dari nilai $\alpha=5 \%$ yang berarti pinjaman modal UMKM memiliki pengaruh yang signifikan terhadap pertumbuhan ekonomi.

Untuk menjelaskan hasil estimasi dari pengujian secara simultan terhadap semua variabel independen menggunakan Uji-F. Dalam pengujian tersebut terbagi menjadi dua cara pengujian yaitu dengan cara f-statistik dan nilai probabilitas $\mathrm{f}$ statistik. Pada estimasi data panel di Tabel 4.3 menunjukkan nilai f-statistik sebesar 287.3947 dengan nilai f-tabel 2.87, maka dapat diartikan bahwa secara bersamaan variabel tenaga kerja, ekspor dan pinjaman berpengaruh secara signifikan terhadap pertumbuhan ekonomi. Selain itu, nilai probabilitas f-statistik bernilai 0.000000 dengan nilai $\alpha=0.05$, sehingga dapat diartikan bahwa secara bersamaan variabel tenaga kerja, ekspor dan pinjaman modal UMKM berpengaruh secara signifikan terhadap pertumbuhan ekonomi.

Selanjutnya, untuk menjelaskan hasil estimasi dari pengujian setiap variabel independen secara parsial menggunakan Uji-t. Kriteria penilaian uji ini dilakukan dengan membandingkan nilai t-statistik dengan nilai t-tabel serta nilai probabilitas tstatistik dengan nilai $\alpha=0.05$. Nilai t-statistik pada variabel tenaga kerja UMKM 
sebesar 1.970915 sedangkan nilai t-tabel sebesar1.683851, artinya $t_{\text {hitung }}>t_{\text {tabel }}$ maka $\mathrm{H}_{1}$ diterima dan $\mathrm{H}_{0}$ ditolak. Dengan kata lain tenaga kerja UMKM berpengaruh secara signifikan terhadap pertumbuhan ekonomi dengan tingkat kebenaran 95\%. Nilai tstatistik pada variabel ekspor UMKM sebesar 0.543018 dengan nilai t-tabel sebesar 1.683851 maka $\mathrm{H}_{0}$ diterima dan $\mathrm{H}_{1}$ ditolak. Dengan kata lain ekspor UMKM tidak berpengaruh signifikan terhadap pertumbuhan ekonomi dengan tingkat kebenaran 95\%. Kemudian, nilai t-statistik pada variabel pinjaman modal UMKM sebesar 2.191815 sedangkan nilai t-tabel sebesar1.683851 maka $\mathrm{H}_{1}$ diterima dan $\mathrm{H}_{0}$ ditolak. Dengan kata lain pinjaman modal UMKM berpengaruh secara signifikan terhadap pertumbuhan ekonomi dengan tingkat kebenaran $95 \%$.

Kriteria penilaian Uji-t yang kedua menggunakan nilai probabilitas t-statistik yang dibandingkan dengan $\alpha=0.05$. Nilai probabilitas t-statistik pada variabel tenaga kerja UMKMsebesar 0.0572 sama dengan $\alpha=0.05$ yang artinya tenaga kerja UMKM berpengaruh signifikan terhadap pertumbuhan ekonomi. Nilai probabilitas t-statistik ekspor UMKM sebesar 0.5908 lebih besar dari $\alpha=0.05$ sehingga dapat diartikan bahwa ekspor UMKM tidak berpengaruh signifikan terhadap pertumbuhan ekonomi. Pada nilai probabilitas t-statistik variabel pinjaman modal UMKM senilai 0.0356 lebih kecil dari nilai $\alpha=0.05$ yang menunjukkan bahwa pinjaman modal UMKM berpengaruh signifikan terhadap pertumbuhan ekonomi.

Pengujian statistik yang terakhir adalah koefisien determinasi yang dapat dilihat pada nilai $R$-Squared. Koefisien determinasi atau $\mathrm{R}^{2}$ digunakan untuk melihat besarnya pengaruh dari variabel independen terhadap variabel dependen. Berdasarkan hasil pengujian pada Tabel 4.8, dapat dilihat jika nilai $R$-squared sebesar 0.981222 , sehingga dapat diartikan bahwa pengaruh variabel tenaga kerja, ekspor dan pinjaman modal UMKM berpengaruh terhadap pertumbuhan ekonomi yaitu sebesar $98.12 \%$ dan sisanya dipengaruhi oleh faktor lain.

Selanjutnya dilakukan uji asumsi klasik yang terdiri dari uji normalitas, uji heteroskedastisitas, uji multikolinieritas dan uji autokorelasi. Model pada penelitian ini lolos asumsi klasik kecuali uji autokorelasi. Pada fixed effect model, nilai Durbin Watson senilai 0.464252 dengan nilai dL sebesar 1.285 dan nilai dU sebesar 1.721 . Kemudian jika dihitung nilai 4-dU sebesar 2.279 dan nilai 4-dL sebesar 2.715. Sehingga dapat disimpulkan bahwa model pada penelitian ini terjadi masalah autokorelasi positif, karena nilai Durbin Watson lebih kecil dari nilai dL. Menurut Gujarati (2012:237) uji asumsi klasik tidak diperlukan dalam analisis data panel karena penelitian yang menggunakan data panel dapat meminimalkan segala sesuatu yang kemungkinan besar muncul dalam hasil analisis. Menurut Basuki (2016:297) berpendapat jika pada dasarnya uji autokorelasi yang dilakukan pada data panel atau cross section hanya akan sia-sia saja, karena autokorelasi akan terjadi pada data time series.

\subsection{Pembahasan}

\subsubsection{Hasil Estimasi Individual Effect pada Model Fixed Effect}

Pada estimasi Individual Effect, jika nilai koefisien positif menunjukkan adanya peningkatan pertumbuhan ekonomi yang terjadi di ASEAN 4 tidak dipengaruhi oleh variabel independen dari model penelitian, melainkan karena adanya faktor lain diluar model dengan asumsi variabel independen bersifat konstan. Sedangkan jika nilai koefisien negatif menunjukkan bahwa petumbuhan ekonomi di ASEAN 4 dipengaruhi oleh variabel independen yaitu tenaga kerja UMKM, nilai 
ekspor UMKM, dan nilai pinjaman modal UMKM. Besar kecilnya pertumbuhan ekonomi yang terjadi dipengaruhi oleh variabel independen sebesar nilai koefisien pada Induvidual Effect.

Tabel 4. Hasil estimasi Individual Effect pasa model Fixed Effect

\begin{tabular}{|c|l|c|}
\hline No & \multicolumn{1}{|c|}{ CROSS ID } & EFFECT \\
\hline 1 & Indonesia & 14.45255 \\
\hline 2 & Thailand & -10.28011 \\
\hline 3 & Filipina & 1.813491 \\
\hline 4 & Malaysia & -5.985928 \\
\hline
\end{tabular}

Sumber: Data diolah, 2021

Berdasarkan Tabel 4 menunjukkan bahwa terdapat dua negara yang memiliki nilai koefisien positif yaitu Negara Indonesia dan Filipina. Hal tersebut berarti pertumbuhan ekonomi di Indonesia tidak dipengaruhi oleh variabel independen pada model. Berdasarkan data ADB, di Indonesia memiliki jumlah UMKM yang banyak, pada tahun 2018 jumlah UMKM di Indonesia sebanyak 99.9\% dari total usaha yang ada. Namun, banyaknya jumlah UMKM tidak sebanding dengan nilai ekspor dan pinjaman yang dilakukan UMKM. Nilai Ekspor yang dilakukan UMKM didua negara ini masih rendah dibandingkan dengan nilai ekspor Usaha Besar. Pada tahun 2018, nilai ekspor UMKM sebesar $14.4 \%$ dari total ekspor seluruh usaha yang ada dan nilai pinjaman modal sebesar $6.96 \%$ dari total pinjaman modal usaha-usaha (UMKM dan UB) di Indonesia. Maka hal tersebut yang menyebabkan pertumbuhan ekonomi di Indonesia tidak disebabkan oleh variabel independen pada model. Selain itu, Filipina juga memiliki nilai koefisien positif pada estimasi Individual Effect. Sama halnya dengan Indonesia, Filipina juga memiliki nilai ekspor dan pinjaman modal UMKM yang rendah dibandingkan dengan negara lainnya. Pada tahun 2018, nilai ekspor UMKM sebesar $22.4 \%$ dan nilai pinjaman modal sebesar $3.3 \%$ dari total pinjaman modal usaha-usaha (UMKM dan UB) di Filipina.

Dua negara lainnya memiliki nilai koefisien negatif, yaitu negara Malaysia dan Thailand. Nilai koefisien negatif tersebut menunjukkan bahwa pertumbuhan ekonomi yang terjadi di Malaysia dan Thailand dipengaruhi oleh jumlah tenga kerja UMKM, nilai ekspor UMKM dan nilai pinjaman modal UMKM. Meskipun nilai GDP UMKM yang tidak terlalu besar dibandingkan negara Indonesia, akan tetapi pertumbuhan ekspor dan pinjaman UMKM dikedua negara tersebut memiliki nilai yang cukup besar diabndingkan dengan Indonesia dan Filipina. Nilai ekspor UMKM di Thailand sebesar $28.74 \%$, sedangkan nilai ekspor UMKM di Malaysia sebesar $17.3 \%$ dari total ekspor usaha-usaha (UMKM dan UB) ditahun 2018. Selanjutnya, nilai pinjaman UMKM di Thailand sebesar $31.63 \%$, sedangkan nilai pinjaman modal UMKM di Malaysia sebesar $22.13 \%$ dari total pinjaman modal usaha-usaha (UMKM dan UB) ditahun 2018 .

\subsubsection{Pengaruh Tenaga Kerja UMKM terhadap Pertumbuhan Ekonomi}

Tenaga kerja memiliki pengaruh positif dan signifikan terhadap pertumbuhan ekonomi di ASEAN 4 (Indonesia, Malaysia, Filipina dan Thailand). Hal tersebut sejalan dengan penelitian yang dilakukan oleh Rohman (2019) mengenai pengaruh perkembangan Usaha Mikro Kecil Menengah terhadap pertumbuhan ekonomi di Indonesia, dimana salah satu variabel independenya yaitu tenaga kerja. Hasil dari penelitian ini menunjukkan bahwa variabel independen, khususnya tenaga kerja 
memiliki pengaruh yang positif dan signifikan terhadap pertumbuhan ekonomi di Indonesia. Dari penelitian ini tenaga kerja merupakan variabel yang paling dominan mempengaruhi PDB. Hal tersebut dapat diinterpretasikan bahwa jika naik turunnya pertumbuhan ekonomi dipengaruhi oleh tenaga kerja. Banyaknyanya tenaga kerja yang dapat diserap oleh UMKM, maka akan mengurangi tingkat pengangguran dan dapat mendorong terjadinya pertumbuhan ekonomi yang semakin meningkat.

Hasil penelitian tersebut sejalan dengan Teori Ekonomi Klasik yang disampaikan oleh Adam Smith. Teori ini menyatakan bahwa pertumbuhan penduduk disuatu wilayah jika diiringi dengan adanya perubahan teknologi akan meningkatkan skala produksi dalam suatu perekonomian sehingga dapat mendorong terjadinya investasi (Sukirno 2007). Banyaknya lapangan pekerjaan akan menyebabkan jumlah tenaga kerja yang diserap meningkat sehingga menambah tingkat produksi, sedangkan tingkat pertumbuhan penduduk menyatakan ukuran besar kecilnya pasar domestik. Jika pertumbuhan penduduk meningkat maka ukuran pasar domestik akan lebih besar dan sebaliknya. Namun, pertumbuhan penduduk dapat berpengaruh positif maupun negatif tergantung sistem perekonomian disuatu daerah terkait kemampuan dalam penyerapan tenaga kerja dan pemanfaatan tenaga kerja yang semakin meningkat disetiap tahunnya. Kemampuan sistem perekonomian tersebut dipengaruhi oleh faktor-faktor yang dapat menunjang perekonomian, seperti akumulasi modal, kecakapan manajerial, dan kualitas tenaga kerja dalam suatu negara.

Tenaga kerja yang ada di suatu negara dapat diserap oleh para produsen, karena peran produsen yang paling utama yaitu menyediakan lapangan pekerjaan dan menyerap tenaga kerja. Saat ini banyak produsen yang menjalankan bisnisnya dalam bentuk UMKM, hal tersebut dapat dilihat dari banyaknya jumlah UMKM yang ada di suatu negara. Jumlah UMKM yang ada di empat negara ASEAN pada tahun 2018 ratarata sebanyak $99.4 \%$ dari total usaha yang ada di empat negara tersebut. Banyaknya jumlah UMKM yang ada diempat negara tersebut dapat menyerap tenaga kerja yang juga semakin banyak. Penyerapan tenaga kerja oleh UMKM yang paling banyak yaitu negara Indonesia sebanyak 116,98 juta jiwa atau sebesar 97\% dari total tenaga kerja yang diserap usaha-usaha (UMKM dan UB) di Indonesia pada tahun 2018. Sedangkan jumlah penyerapan tenaga kerja oleh UMKM ditahun 2018 yang paling rendah yaitu negara Filipina sebanyak 5,71 juta jiwa atau sebesar 63.2\% dari total tenaga kerja yang diserap usaha-usaha (UMKM dan UB) yang ada di Filipina.

Jumlah tenaga kerja yang banyak diserap oleh UMKM di Indonesia menyebabkan tingginya kontribusi UMKM terhadap GDP yaitu sebesar $61.1 \%$ dari total GDP usaha-usaha yang ada di Indonesia ditahun 2018, nilai tersebut lebih tinggi dibandingkan dengan negara lainnya. Sebaliknya, di Filipina tenaga kerja yang diserap oleh UMKM lebih sedikit dari pada negara lain, sehingga kontribusi UMKM terhadap GDP di Filipina rendah yaitu sebesar 38.6\% dari total GDP usaha-usaha di Malaysia ditahun 2018. Hal tersebut menunjukkan bahwa jumlah tenaga kerja yang diserap oleh UMKM akan mempengaruhi pertumbuhan ekonomi yang dilihat dari nilai GDP di suatu negara. Banyaknya tenaga kerja yang diserap oleh UMKM menyebabkan tingginya GDP suatu negara dan sebaliknya, jika tenaga kerja yang diserap oleh UMKM sedikit akan menyebabkan rendahnya GDP suatu negara.

\subsubsection{Pengaruh Ekspor UMKM terhadap Pertumbuhan Ekonomi}

Ekspor yang dilakukan oleh UMKM memiliki pengaruh positif tetapi tidak signifikan terhadap pertumbuhan ekonomi di ASEAN 4 (Indonesia, Malaysia, Filipina 
dan Thailand). Hasil tersebut sama dengan penelitian yang dilakukan oleh Riswara (2018) yang meneliti mengenai pengaruh UKM terhadap perekonomian Indonesia tahun 1996-2016. Hasil penelitian menunjukkan bahwa variabel ekspor tidak memiliki hubungan yang signifikan terhadap pertumbuhan ekonomi yang dilihat dari PDB. Penelitian lainnya yaitu penelitian yang dilakukan oleh Asbiantari et al. (2016) mengenai pengaruh ekspor terhadap pertumbuhan ekonomi Indonesia. Hasil penelitian tersebut menunjukkan bahwa variabel ekspor tidak memiliki hubungan yang signifikan baik dalam jangka pendek maupun jangka panjang. Begitu pula dengan penelitian Mahzalena and Juliansyah (2019) yang meneliti tentang pengaruh innflasi, pengeluaran pemerintah dan ekspor terhadap pertumbuhan ekonomi di Indonesia. Hasil penelitian ini menunjukkan bahwa ekspor berpengaruh negatif dan tidak signifikan terhadap pertumbuhan ekonomi.

Kegiatan ekspor yang dilakukan UMKM di empat negara ASEAN masih rendah jika dibandingkan dengan ekspor yang dilakukan oleh Usaha Besar (UB) dimasing-masing negara, sehingga hal tersebut menyebabkan nilai ekspor berpengaruh positif namun tidak signifikan. Dari tahun 2009-2018 rata-rata hanya sebesar 20.2\% dari total ekspor usaha-usaha (UMKM dan UB) yang dilakukan oleh empat negara ASEAN. Nilai ekspor yang paling besar diantara empat negara ASEAN, yaitu Thailand. Pada tahun 2009, nilai ekspor UMKM di Thailand sebesar $30.1 \%$ dan ditahun 2018 sebesar 28.7\% dari total ekspor usaha-usaha (UMKM dan UB) di Thailand. Sedangkan, nilai ekspor UMKM yang paling rendah yaitu negara Indonesia yaitu sebesar 16.8\% ditahun 2009 dan 14.4\% ditahun 2018 .

Nilai ekspor UMKM masih cukup rendah, hal tersebut tidak sebanding dengan banyaknya jumlah UMKM di 4 Negara ASEAN tersebut. Maka, hendaknya UMKM terus melakukan produksi yang berorientasi ekspor, karena barang-barang yang diproduksi oleh UMKM sebagian besar masih dikerjakan oleh manusia, sehingga barang yang dihasilkan sangat bagus dan rapi disetiap detailnya. Hal tersebut menunjukkan bahwa kualitas barang UMKM lebih bagus dibandingkan dengan barang yang diproduksi oleh Usaha Besar. Selain itu barang hasil UMKM sangat identik dengan ciri khas dan kebudayaan negaranya, sehingga menarik minat konsumen dari negara lain untuk membeli.

\subsubsection{Pengaruh Pinjaman UMKM terhadap Pertumbuhan Ekonomi}

Berdasarkan hasil penelitian pinjaman modal yang dilakukan UMKM memiliki pengaruh positif dan signifikan terhadap pertumbuhan ekonomi di negara ASEAN, khususnya di Indonesia, Malaysia, Filipina dan Thailand. Negara dengan nilai pinjaman modal UMKM terbesar adalah Thailand dimana pada tahun 2018 sebesar 202.155 juta USD. Sedangkan, negara dengan nilai pinjaman UMKM terendah adalah negara Filipina sebesar 10.957 juta USD pada tahun 2018. Tingginya nilai pinjaman modal di Thailand dibandingkan dengan negara lain menyebabkan negara dengan nilai pinjaman modal yang lebih rendah cenderung memiliki nilai pertumbuhan ekonomi yang rendah.

Hal tersebut sejalan dengan beberapa penelitian yang dilakukan oleh Dwiastuti (2020) yang meneliti tentang pengaruh kredit perbankan terhadap pertumbuhan ekonomi dan hubungannya dengan kesejahteraan masyarakat Kabupaten/Kota di Provinsi Kalimantan Barat. Penelitian tersebut menunjukan bahwa kredit modal kerja berpengaruh positif dan tidak signifikan terhadap pertumbuhan ekonomi Kabupaten/Kota di Provinsi Kalimantan Barat. Selain itu, penelitian yang dilakukan 
oleh Tahang et al. (2017), yang menganalisis pengaruh kredit perbankan terhadap pertumbuhan ekonomi Provinsi Sulawesi Tenggara. Penelitian ini menunjukan bahwa kredit modal kerja berpengaruh signifikan dan positif terhadap pertumbuhan ekonomi sektor pertambangan, sektor konstruksi, dan sektor perdagangan pada taraf kepercayaan $5 \%$. Sedangankan pengaruh kredit modal kerja terhadap pertumbuhan ekonomi sektor pertanian, industri, listrik, pengangkutan, keuangan, dan jasa-jasa tidak signifikan.

Selain itu, Teori Neo-klasik menjelaskan tentang fungsi produksi suatu barang atau jasa tergantung pada modal dan tenaga kerja yang digunakan dalam proses produksi. Dalam kegiatan produksi banyak kendala yang dihadapi para pelaku usaha yang meliputi produksi, pengolahan, pemasaran modal, dan lainnya. Dari berbagai kendala yang dihadapi, maka diperlukan strategi seperti kemitraan dan bantuan keuangan. Salah satu bantuan keuangan beruoa pinjaman modal sangat penting karena sebagian besar pelaku usaha mengalami hambatan permodalan untuk melakukan investasi baru atau dalam melakukan perubahan teknologi. Dalam teori ekonomi mikro dijelaskan bahwa tingginya pinjaman modal yang dilakukan oleh para pelaku usaha dapat meningkatkan akses finansial yang akan mendorong kemampuan usaha dalam melakukan ekspansi usaha dan perluasan pasar. Sehingga, peran pinjaman modal terhadap perekonomian menjadi penting terutama dalam mempercepat laju pertumbuhan ekonomi Supartoyo et al. (2018).

\section{SIMPULAN, KETERBATASAN, DAN SARAN}

Penelitian tentang pengaruh perkembangan usaha mikro kecil dan menengah (UMKM) terhadap pertumbuhan ekonomi di 4 negara ASEAN yang meliputi Negara Indonesia, Malaysia, Filipina dan Thailand memberikan kesimpulan sebagai berikut:

1. Jumlah tenaga kerja UMKM berpengaruh positif dan signifikan terhadap pertumbuhan ekonomi di empat negara ASEAN. Hal tersebut dikarenakan Negara Indonesia, Malaysia, Filipina dan Thailand memiliki persentase tenaga kerja yang diserap oleh UMKM pada tahun 2009-2018 sebesar 75.5\% dari total tenaga kerja yang ada dimasing-masing negara. Sehingga banyaknya penyerapan tenaga kerja oleh UMKM menyebabkan output yang dihasilkan UMKM meningkat dan nilai GDP negara juga ikut meningkat.

2. Ekspor yang dilakukan oleh UMKM berpengaruh positif dan tidak signifikan terhadap pertumbuhan ekonomi di empat negara ASEAN. Hal tersebut dikarenakan Negara Indonesia, Malaysia, Filipina dan Thailand memiliki persentase ekspor UMKM pada tahun 2009-2018 sebesar 20.2\% dari total ekspor dimasing-masing negara. Nilai tersebut masih cukup rendah jika dibandingkan dengan ekspor yang dilakukan oleh usaha selain UMKM.

3. Pinjaman modal yang dilakukan oleh UMKM berpengaruh positif dan signifikan terhadap pertumbuhan ekonomi di empat negara ASEAN. Hal tersebut dikarenakan Negara Indonesia, Malaysia, Filipina dan Thailand memiliki persentase pinjaman modal UMKM pada tahun 2009-2018 sebesar 15.4\% dari total ekspor dimasing-masing negara. Sehingga nilai pinjaman modal tersebut menyebabkan terjadinya perkembangan UMKM yang dapat meningkat nilai GDP negara juga ikut meningkat.

Berdasarkan penjelasan dari kesimpulan terkait pengaruh perkembangan

Usaha Mikro Kecil dan Menengah terhadap pertumbuhan ekonomi di 4 Negara ASEAN, peneliti memberikan beberapa saran, antara lain. 
1) UMKM khususnya yang ada di 4 Negara ASEAN tidak hanya menjual output yang dihasilkan didalam pasar domestik saja, namun juga harus menjual output ke pasar internasional karena sampai saat ini masih sedikit nilai ekspor yang dilakukan UMKM. Para pelaku UMKM harus lebih percaya jika output yang dihasilkan memiliki ciri dan karakteristik yang unik dibandingkan dengan output yang dihasilkan oleh Usaha Besar.

2) UMKM hendaknya lebih meningkatkan kualitas output yang dihasilkan dan harus bisa menghasilkan barang jadi, karena masih banyak UMKM yang hanya menghasilkan barang setengah jadi. Barang jadi memiliki nilai tambah yang lebih tinggi dari pada barang setengah jadi.

3) Usaha Besar khususnya yang ada di 4 Negara ASEAN hendaknya memberi kesempatan bagi UMKM sebagai penyedia bahan baku atau input dalam proses produksinya bukan malah menggeserkan UMKM.

\section{DAFTAR PUSTAKA}

Anne, N. F., D. S. Fajrin, dan C. Syaa. 2017. Pengaruh Kinerja Mitra Binaan (UMKM) Terhadap Pertumbuhan Ekonomi di Indonesia (Studi Kasus : UMKM Mitra Binaan CSR\&SMEPP Jatim BaliNus MOR V). ISEI Economic Review 1 (1):20-25.

Asbiantari, D. R., M. P. Hutagaol, dan A. Asmara. 2016. Pengaruh Ekspor Terhadap Pertumbuhan Ekonomi Indonesia. Jurnal Ekonomi dan Kebijakan Pembangunan 5 (2):10-31.

Dwiastuti, N. 2020. Pengaruh Kredit Perbankan Terhadap Pertumbuhan Ekonomi dan Hubungannya Dengan Kesejahteraan Masyarakat Kabupaten/Kota di Provinsi Kalimantan Barat. Prosiding Seminar Akademik Tahunan Ilmu Ekonomi dan Studi Pembangunan 5 (7).

Febryani, T. 2017. Determinasi Pertumbuhan Ekonomi di 4 Negara ASEAN. JIET (Jurnal Ilmu Ekonomi Terapan) 2 (1):10-20.

Halim, A. 2020. Pengaruh Pertumbuhan Usaha Mikro Kecil dan Menengah terhadap Pertumbuhan Ekonomi Kabupaten Mamuju. Jurnal Ilmiah Ekonomi 1 (2).

Hapsari, P. Paramita, A. Hakim, dan I. Noor. 2014. Pengaruh Pertumbuhan Usaha Kecil Menenga (UKM) terhadap Pertumbuhan Ekonomi Daerah (Studi di Pemerintahan Kota Batu). Wacana Journal of Social and Humanity Studies 17 (2):88-96.

Hidayati, N. 2016. Pengaruh Pertumbuhan Usaha Mikro Kecil Menengah (UMKM) terhadap Pertumbuhan Ekonomi Daerah Kabupaten Bogor Periode 2012-2015. Skripsi, Universitas Syarif Hidayatullah, Jakarta.

Mahzalena, Y., dan H. Juliansyah. 2019. Pengaruh Inflasi, Pengeluaran Pemerintah dan Ekspor Terhadap Pertumbuhan Ekonomi di Indonesia. Jurnal ekonomi Regional Unimal 2 (1):37-50.

Rachman, S. 2017. Analisis Pengaruh Perkembangan Usaha Kecil dan Menengah Sektor Manufaktur Terhadap Pertumbuhan Ekonomi di Kota Makassar. Jurnal Administrare 3 (2):71-82.

Riswara, Y. H. 2018. Pengaruh UKM Terhadap Pertumbuhan Ekonomi Indonesia Tahun 1999-2016. Skripsi, Universitas Islam Indonesia, Yogyakarta. 
Rohman, R. N. 2019. Analisis Pengaruh Perkembangan Usaha Mikro Kecil Menengah Terhadap Pertumbuhan Ekonomi di Indonesia Tahun 1997-2017. Skripsi, Ilmu Ekonomi dan Studi Pembangunan, Universitas Muhammadiyah Surakarta, Yogyakarta.

Sukirno, S. 2007. Ekonomi Pembangunan (Proses, masalah, dan kebijakan). Jakarta: Kencana Prenada.

Supartoyo, Y. H., B. Juanda, M. Firdaus, dan J. Effendi. 2018. Pengaruh Sektor Keuangan Bank Perkreditan Rakyat terhadap perekonomian regional Wilayah Sulawesi. Kajian Ekonomi dan Keuangan 2 (1):16-37.

Tahang, M., M. Syarif, dan B. Baheri. 2017. Analisis Pengaruh Kredit Perbankan Terhadap Pertumbuhan Ekonomi Provinsi Sulawesi Tenggara. JPEP (Jurnal Progress Ekonomi Pembangunan 2 (2).

Tambunan, T. T. H. 2000. Usaha Kecil dan Menengah di Indonesia. Jakarta: Salemba Empat. 